\title{
Newspaper quality, content and competition in New Zealand
}

\section{ABSTRACT}

Content analysis results show that investment strategies and newspaper quality vary between companies in New Zealand. Indeed, Allied Press' Otago Daily Times prints considerably more news than Fairfax papers with similar circulations, and almost as much news as the Christchurch Press. The results also provide some support for the theory that producing a relatively high quality newspaper, when quality is measured by the quantity of news published and number of journalists employed, is associated with relatively high readership. Vigorous competition between companies for dominance in the Queenstown newspaper market suggests that less concentrated newspaper ownership could increase competition and benefit consumers in other parts of New Zealand. Although the results are from 2006, strong similarities between the newspapers surveyed and more recent issues of these titles means the results and policy lessons drawn are still relevant.

Keywords: Allied Press, Christchurch Press, content analysis, Fairfax New Zealand, media ownership, newspapers, newspaper competition, newspaper quality, Otago Daily Times, Southland Times, Waikato Times

\section{MATTHEW GIBBONS \\ University of Waikato}

7 HE MEDIA play a key role in informing people about events, facilitating political learning, ensuring surveillance of political and economic actors, promoting public discussion and civic engagement, and in creating a sense of community (Kemp, 2010, pp. 385-397). Because of their relatively high information content, newspapers play a particu- 
larly important role in informing and educating people. Compared to nonreaders, regular newspaper readers are more trusting, more likely to vote, and more knowledgeable about current events (Gentzkow, Shapiro, \& Sinkinson, 2011; Hindman \& Yamamoto, 2011; Norris, 2000, pp. 315-319). In many communities newspapers employ the most journalists, and other media sources are heavily dependent on newspapers for news stories.

This article quantifies the amount and type of news printed in New Zealand's third to sixth largest circulation newspapers during a typical week in 2006. An estimate is also made of the number of journalists writing for these newspapers. The papers in the sample are the Otago Daily Times, which is published by a locally owned Dunedin company, and the Christchurch Press, Waikato Times and the Southland Times, which are owned by the Australian company Fairfax. The data collected provides insights into the relationship between newspaper ownership, content and quality, and less robustly into the relationship between the quality of newspapers and readership levels.

\section{Overseas research on newspaper competition and quality}

The literature on newspaper competition and quality is most advanced for the United States. Surveys of regional United States newspaper editors, whose focus is largely on attracting readers and advertisers, usually consider the quantity of news published, particularly about the paper's local region, and the number of journalists employed as the most important indicators of newspaper quality. Other important variables identified in surveys include a high level of staff written material, using a wide range of external news agencies, publishing a large number of letters to the editor and opinion columns, and a high use of pictures (Cho, Thorson, \& Lacy, 2004, p. 36; Lacy \& Fico, 1991, p. 51). The importance of localism for commercial success appears to vary between countries; regional newspapers in Britain have been performing poorly compared to national newspapers except in remote areas (Tryhorn, 2010).

Newspapers with larger circulations tend to score better on quality indexes. However, there are often considerable differences in quality between newspapers with similar circulations but different owners, with investment strategies varying between companies (Lacy \& Fico, 1990, pp. 48, 51-52). Researchers have often found that better quality newspapers have higher circulations, readership, and advertising revenue than lower-quality news- 
papers serving similar markets (Chen, Thorson, \& Lacy, 2005, pp. 521-526; Cho et al., 2004, pp. 24-36). Strong relationships between newsroom investment and financial performance suggest that cutting staff and pagination is often counterproductive, even in the short-term (Chen et al., 2005, p. 526).

The statistical significance of the link between newspaper quality and circulation has been questioned. However, there is strong evidence that the quality of United States newspapers, as defined by regional newspaper editors, is relatively high in the most competitive markets. Because most cities now only have one daily paper, competition is often on a regional basis. For instance, in the twin cities of Dallas-Fort Worth (Texas), Minneapolis-St Paul (Minnesota), and Tampa Bay-St Petersburg (Florida), rival papers are fighting for market dominance, especially in new suburbs, and this competition results in relatively high quality newspapers and readership rates (Meyer, 2009, pp. 156-158, 188). Less intense competition for market share between national, metropolitan, and local newspapers also promotes newspaper quality and readership (Fan, 2009; Lacy, 1988).

\section{Newspaper competition in New Zealand}

Ownership of newspapers in New Zealand is extremely concentrated (Molineaux, 1995; Rosenberg, 2007, p. 176) and New Zealand no longer has competing daily newspapers published in the same city. Nevertheless, there is still some competition at a regional level. In particular, some morning newspapers have circulation areas that extend well beyond their home city, and compete with more locally focussed papers. For instance, although the New Zealand Herald is published in Auckland, it is home delivered in the upper half of the North Island and competes with smaller papers such as Hamilton's Waikato Times. Partly in response to Auckland's Herald becoming more widely available in Wellington, in 2002 INL combined its morning and evening Wellington newspapers into a larger paper called the Dominion Post (Cohen, 2004).

A focus of this article is on the strong regional competition in the lower half of the South Island where Allied Press' Otago Daily Times is competing with Fairfax morning newspapers such as the Christchurch Press, Timaru Herald, and the Southland Times. The Otago Daily Times is home delivered in Timaru in South Canterbury, and in parts of Southland. Likewise, the Press is widely available in Otago. The Southland Times brings out an edition with 
"Queenstown and Central Otago edition" in large red capital letters on the masthead, which is substantially different to the Southland edition. All three papers are fighting for market share in Queenstown, where only a free weekly newspaper is published. However, the Press arrives there too late $(10 \mathrm{am})$ to have much market share (Guthrie \& Julian, 2009, p. 2).

Queenstown is an attractive market because its population has been growing rapidly. Between 2001 and 2006 the Queenstown Lakes District was the fastest growing territorial authority in New Zealand, with a 29.6 percent increase in population to a census night population of 32,592 (Statistics New Zealand, 2006). There has also been recent population growth in Central Otago.

\section{Previous assessments of newspaper quality in New Zealand}

There have been several important studies of newspaper quality in New Zealand. As in other countries, researchers have tended to focus on the quantity and type of news published and on staff numbers, although the quality, accuracy and balance of reporting has also been considered important.

In a pioneering study Elizabeth Warburton measured the space occupied by different types of news in New Zealand's four biggest circulation morning papers in 1953. She found that in terms of total amount of serious news, New Zealand newspapers compared well to British newspapers (Warburton, 1954, pp. 173-174, 198). Media reporters have often reported the total number of pages in a newspaper, and have regarded as important the space allocated to local news relative to advertisements, New Zealand Press Agency (NZPA) stories, and general interest material from overseas agencies (Ovenden, 1987, pp. 72-76; Roger, 2002, p. 95). Occasionally reporters have even measured the total editorial space. For instance, Marcia Russell (1991) found that the Saturday edition of the New Zealand Herald had a considerably lower ratio of editorial to advertising material than the next day's Sunday Star (Russell, 1991, p. 164). Journalists have also shown that editorial space was higher in the Herald in 2008 than in 1988, although there had been a shift from harder news towards entertainment and lifestyle stories (EPMU New Zealand Herald Journalists, 2009).

Journalists, media commentators, and sometimes even newspaper managers, have identified the level of editorial resources as being vital for a newspaper's success (Max, 1986, pp. 50-51; McGregor, 1996, p. 12). Snapshots of staffing levels at some newspapers have been published and some of 
the reductions in staffing since the 1980s have been quantified (Ellis, 2010, p. 409; EPMU New Zealand Herald Journalists, 2009).

\section{Methods and sample}

This article primarily assesses the quality of newspapers on the basis of the quantity and type of news they publish, although data on the numbers of journalists they employ is also evaluated. These variables are prominent in the international and New Zealand literature on newspaper quality, while data collection is relatively straightforward. Other quality measures, such as depth of analysis, the diversity of editorial material, and the inclusion of stories about Māori or about other groups, are unfortunately beyond the scope of this article. As a result, its conclusions are tentative.

The sample is drawn from New Zealand's third to sixth largest circulation newspapers in 2006, which were (and still are) the Press, the Otago Daily Times, the Waikato Times, and the Southland Times (the Queenstown and Central Otago edition was used). Because of the effect of a paper's sales on its pagination and staffing, it is important to compare papers with similar circulations. Table 1 outlines key data about these papers.

Dunedin's Allied Press owns the Otago Daily Times. In contrast, the Australian company Fairfax has owned the other three papers since 2003, when it purchased INL's New Zealand newspapers. The sample includes three papers from the South Island, and Hamilton's Waikato Times from the North Island.

\begin{tabular}{|c|c|c|c|c|}
\hline Paper & Press & $\begin{array}{c}\text { Otago Daily } \\
\text { Times }\end{array}$ & $\begin{array}{l}\text { Waikato } \\
\text { Times }\end{array}$ & $\begin{array}{c}\text { Southland } \\
\text { Times }\end{array}$ \\
\hline Owner & Fairfax & Allied Press & Fairfax & Fairfax \\
\hline City published & Christchurch & Dunedin & Hamilton & Invercargill \\
\hline City population $2006^{1}$ & 361,491 & 123,516 & 132,060 & 51,021 \\
\hline Regional population 2006 & 541,515 & 209,850 & 393,171 & 95,247 \\
\hline Circulation 2006 & 92,465 & 43,246 & 41,083 & 29,571 \\
\hline AM or PM & AM & AM & $\begin{array}{l}\text { PM except } \\
\text { Saturday }\end{array}$ & AM \\
\hline Weekly price & $\begin{array}{l}\$ 1.10 \text { (95c } \\
\text { delivered) }\end{array}$ & $\begin{array}{l}\$ 1.00(75 c \\
\text { delivered) }\end{array}$ & $\$ 1.00$ & $\begin{array}{c}90 c(80 c \\
\text { delivered) }\end{array}$ \\
\hline Saturday price & $\$ 2.00$ & $\begin{array}{l}\$ 1.70(75 \mathrm{c} \\
\text { delivered) }\end{array}$ & $\$ 1.70$ & $\$ 1.30$ \\
\hline
\end{tabular}

Source: www.stats.govt.nz/Census/about-2006-census/final-counts-tables.aspx 
The Waikato Times had almost exactly the same circulation as the Otago Daily Times, while Hamilton has a similar population to Dunedin. These similarities make comparisons between the two papers particularly appropriate.

The regional population statistics in Table 1 are sometimes contested. For instance, although Otago excludes half the Waitaki District, the Otago Daily Times considers the Waitaki part of its core circulation area (Wood, 1975, p. 269). While the Queenstown Lakes District is part of the Otago Regional Council, in 2006 the Southland District Health Board ran Queenstown's hospital.

To ensure short-term events did not affect the results, data was collected for a constructed week. This is the sample period usually used in other countries (Riffe, Aust, \& Lacy, 1993, p. 138) and resulted in the papers for each day of the week being collected during different weeks between August and November 2006. All sections of the newspapers were measured and the sample included the Waikato Times' monthly 'Home \& Lifestyle' tabloid. While using data from a constructed week should enable a valid overall comparison of the papers, when there is only a small amount of news on a topic or locality drawing a sample from a different week might alter the results.

Initially data was collected for the four papers for a single day as part of a media studies class exercise in content analysis techniques. Funding for measuring the Otago Daily Times and Southland Times for an entire week was the provided by Allied Press, which was interested in how the two newspapers compared. However, Allied Press did not seek to influence the dates selected for the constructed week or the methods used. The author measured the remaining issues of the Press and Waikato Times while on vacation. Resource constraints unfortunately preclude expanding the sample. While similarities between papers surveyed and recent issues of the same titles are strong, a later section discusses changes to the papers since 2006.

The content analysis techniques used reflected methods developed overseas. The area covered by print on each page was measured. Content was categorised as news (all material under the control of editorial staff), advertising (including advertising features) and promotional material (such as mastheads). News stories were coded according to their type, with section headings used as a guide, while they were also classified according to whether they were predominantly tabular items, such as stock market listings and crosswords. Further details are available from the author. 


\begin{tabular}{|l|c|c|c|c|}
\hline & Table 2: Key attributes of the news paper studied \\
\hline & Press & $\begin{array}{c}\text { Otago Daily } \\
\text { Times }\end{array}$ & $\begin{array}{c}\text { Waikato } \\
\text { Times }\end{array}$ & $\begin{array}{c}\text { Southland } \\
\text { Times }\end{array}$ \\
\hline Pages of news & 158.2 & 150.3 & 110.8 & 87.9 \\
\hline Pages of advertising & 243.9 & 202.6 & 168.9 & 121.6 \\
\hline Promotional pages & 25.5 & 10.5 & 19.5 & 8.3 \\
\hline Total number of pages & 427.5 & 363.3 & 299.3 & 217.8 \\
\hline & & & & \\
\hline Percentage that is news & $36.8 \%$ & $41.4 \%$ & $37.0 \%$ & $40.4 \%$ \\
\hline Advertising percentage & $57.0 \%$ & $55.8 \%$ & $56.4 \%$ & $55.8 \%$ \\
\hline Non-tabular news & $79 \%$ & $77 \%$ & $85 \%$ & $78 \%$ \\
\hline $\begin{array}{l}\text { Percentage of news written by } \\
\text { paper's own writers }\end{array}$ & $43 \%$ & $45 \%$ & $47 \%$ & $40 \%$ \\
\hline $\begin{array}{l}\text { Percentage of news on Mondays } \\
\text { that has pictures }\end{array}$ & $20 \%$ & $24.7 \%$ & $29.9 \%$ & $22.0 \%$ \\
\hline
\end{tabular}

Confidential data on newspaper staff numbers and costs is available in some countries, although for individual papers only publicly available information can be reported. This study recorded the names of journalists and the sources of stories. The number of writers who contributed three or more stories was counted. This method has limitations, and this article therefore primarily focuses on the quantity of news published.

Fairfax regarded the papers it acquired in 2003 as siloed, undermanaged, and underperforming (Hilmer, 2007, p. 78). Its chief executive singled out the Waikato Times for particular attention, saying that it "needs to jump from being a regional to a metro" (Wilson, 2003). Improvements by late 2006 included the introduction of a TV Week supplement, the use of news from Fairfax's Australian newspapers, and the Saturday edition being enlarged and turned into a morning paper (Hendery, 2009). Fairfax was more satisfied with the Christchurch Press and Southland Times, although the latter was re-designed.

\section{Results for the four papers}

The summary results in Table 2 show that the Press had 158 pages of news during the constructed week, compared to the Otago Daily Times' 150 pages, the Waikato Times' 111 pages and the Southland Times' 88 pages. The Otago Daily Times therefore contained only slightly less news than the Press, despite having less than half the circulation. Indeed, on Monday, Tuesday and Thursday the 
Dunedin paper had more pages of news. Despite having similar circulations, and despite investment by Fairfax, on every day studied the Waikato Times had fewer pages of news than the Otago Daily Times, and had only 74 percent as much news over the entire week.

The Otago Daily Times devoted the highest proportion of its paper to news at 41.4 percent, which was several percent higher than the Press and Waikato Times, but only fractionally higher than the Southland Times. The Press was ahead of the other papers in terms of the quantity of advertising published and total pagination. The Waikato Times had a relatively high proportion of news stories, compared to sports and entertainment listings, and percentage of news written by the paper's own journalists. However, in absolute terms the paper compared poorly to the Otago Daily Times and the Press on both measures. These results suggest that which company owns a newspaper affects the quantity of news it publishes.

Local news is often important to the commercial success of a paper because this news is frequently of greatest personal interest to readers and is unavailable from other sources. Table 3 shows that the Otago Daily Times' local news coverage was almost twice as extensive as that of the other papers. Indeed, the Otago Daily Times published 32.8 broadsheet pages of local news about its home delivery region compared to the 16.8 pages in the Press, 15.5 pages in the Southland Times, and just 13 pages in the Waikato Times. Table 4 indicates that the Otago Daily Times also had considerably more local writers, with 24 journalists contributing three or more local news stories compared to 16 on the Southland Times, 13 on the Press and just eight on the Waikato Times. Admittedly, the Waikato Times had a relatively high number of short local news stories without a by-line, so the results may understate its number of journalists. However, the numbers of staff writing for the Otago Daily Times appear similar to those in 2002 when the paper had 18 Dunedin based news and sports reporters and nine regional reporters based in Alexandra, Balclutha, Oamaru, Queenstown and Wanaka (Tansley, 2002, p. 88). ${ }^{1}$ Whereas the Southland Times had reporters based in Alexandra, Gore, Invercargill, and Queenstown, the Waikato Times appeared to have full-time staff based only in its home city of Hamilton.

Table 3 shows that Press contained 13.5 pages of national news compared to the Otago Daily Times' 9.5, with the other papers well behind. The Press had four reporters contributing three or more national stories (although they 


\begin{tabular}{|l|c|c|c|c|}
\hline & Table 3: Total news and different news types, 2002 \\
\hline & Press & $\begin{array}{c}\text { Otago Daily } \\
\text { Times }\end{array}$ & $\begin{array}{c}\text { Waikato } \\
\text { Times }\end{array}$ & $\begin{array}{c}\text { Southland } \\
\text { Times }\end{array}$ \\
\hline Local news & 16.8 & 32.8 & 13.0 & 15.5 \\
\hline National news & 13.5 & 9.5 & 4.2 & 5.7 \\
\hline Business news & 22.9 & 10.1 & 15.3 & 5.5 \\
\hline World news & 18.3 & 15.3 & 10.0 & 6.7 \\
\hline Editorial, opinion, letters & 8.6 & 9.8 & 5.4 & 5.2 \\
\hline Sports news & 38.7 & 38.8 & 22.6 & 23.5 \\
\hline Entertainment & 19.5 & 19.3 & 17.7 & 13.6 \\
\hline Features, travel, life styles & 14.0 & 9.4 & 18.9 & 8.8 \\
\hline Weather & 2.8 & 2.7 & 2.0 & 2.7 \\
\hline Obituaries & 0.8 & 0.7 & 0.5 & 0.4 \\
\hline Motoring & 2.2 & 1.7 & 1.3 & 0.4 \\
\hline Total & 158.2 & 150.3 & 110.8 & 87.9 \\
\hline
\end{tabular}

Note: Broadsheet page equivalents of total news and different types of news in each newspaper.

would also usually have been supplying copy to other Fairfax papers), whereas the Otago Daily Times relied entirely on NZPA and New Zealand Herald journalists for North Island stories.

The Press (22.9 pages) and Waikato Times (15.3 pages) both had substantially more business news than the Otago Daily Times (10.1 pages) or the Southland Times (5.5 pages). One of the changes Fairfax made to the Waikato Times was re-branding its business pages as Business Day, and giving the paper access to the same stories as the Business Day sections of the Press and Dominion Post (Fairfax, 2004, p. 18). The Press and Waikato Times also had the most staff contributing three or more business stories. While the Otago Daily Times had three business journalists based in Dunedin, the Waikato Times had just two based in Hamilton. Other Business Day journalists who contributed to the Waikato Times were reporting from larger centres, and their stories may not always have been of such direct interest to Waikato readers. For instance, the Waikato Times devoted two-thirds of a page of business news to the collapse of the carpet company Feltex, even though this had little direct effect on the Waikato economy.

The Press printed slightly more world news than the Otago Daily Times, but substantially more than the other two papers. Although some United States regional newspapers have minimal coverage of overseas events (Beaudoin \& 
Table 4: Number of journalists who contributed three or more stories

\begin{tabular}{|l|c|c|c|c|}
\hline & Press & $\begin{array}{c}\text { Otago Daily } \\
\text { Times }\end{array}$ & $\begin{array}{c}\text { Waikato } \\
\text { Times }\end{array}$ & $\begin{array}{c}\text { Southland } \\
\text { Times }\end{array}$ \\
\hline 3+ Local stories & 13 & 24 & 8 & 16 \\
\hline 3+ National stories & 4 & 0 & 0 & 1 \\
\hline 3+ Business news & 10 & 3 & 5 & 3 \\
\hline 3+ Sports news & 9 & 6 & 5 & 7 \\
\hline 3+ Entertainment & 5 & 1 & 4 & 1 \\
\hline 3+ Features, travel, life styles & 2 & 2 & 3 & 2 \\
\hline Total 3+ stories in each category & 43 & 36 & 25 & 30 \\
\hline
\end{tabular}

Thorson, 2001), world news is an important part of the New Zealand newspapers studied. The Otago Daily Times ' world news coverage was strongest on Monday, when it published a 16 page tabloid World Focus section. In contrast, the Press spread its international coverage more evenly over the week. All four papers relied almost exclusively on overseas agencies and newspapers for world news. World news in the Southland Times came from Reuters, AP, AFP, and AAP, and sometimes had been edited by NZPA. The Waikato Times used these agencies, but also included stories from the London Times and Fairfax's Sydney Morning Herald. The Otago Daily Times drew on additional overseas agencies, and also reprinted stories from the Los Angeles Times, Washington Post, Guardian, and Observer. The Press used fewer overseas agencies than the Otago Daily Times, but as well as reprinting stories from the same overseas papers also included stories from the London Times, Sydney Morning Herald, and Baltimore Sun. In terms of the total number of sources for world news, the Press and Otago Daily Times therefore seemed to be about equal.

Table 3 shows that the Otago Daily Times gave editorials, opinion columns and letters more space than any other paper. This content is important for ensuring a newspaper functions as a civic forum for its readers (Norris, 2000, p. 27). As well as devoting most of its editorial page to letters, the paper's Tuesday and Thursday editions published further letters on other pages, whereas among the other papers this happened only in the Press 'Wednesday edition. The Otago Daily Times regularly seeks and prints responses and critical commentary by experts directly alongside readers' letters, which further enhances the information value of this section.

The quantity of space devoted to sports was almost identical in the Press 
(38.7 pages) and Otago Daily Times (38.8 pages), and was substantial at 22.6 pages in the Waikato Times and 23.5 pages in the Southland Times. Excluding tabular material, such as racing listings, sports fixtures, and scoreboards, narrowed the gap and resulted in the Waikato Times overtaking the Southland Times. However, listings are often an important reason why people buy a newspaper. The Press had the greatest number of sports journalists who contributed three or more stories, with the Southland Times having the second highest number. Only the Press and Southland Times had a female sports writer.

Coverage of entertainment was also almost identical in the Press (19.5 pages) and Otago Daily Times (19.3 pages), and was high in the Waikato Times (17.7 pages) and Southland Times (13.6 pages). The Waikato Times published the most extensive television guide (16 tabloid pages) of the papers studied, with its TV Week section containing four more pages of entertainment stories than the Press' similarly named section. The Waikato Times also seemed to be second only to the Press in terms of the number of writers concentrating on entertainment stories, with its film, television and arts reporting being relatively strong.

The Waikato Times devoted more space (18.9 pages) to features, travel and lifestyle than the other papers, and appeared to have the most staff concentrating on this type of story. However, 7.1 pages of this content were in the paper's monthly Home and Lifestyle section, which contains stories largely about people's houses and home renovations. Another 3.8 pages of lifestyles stories were in the Wednesday Tempo section, and some of the Tempo stories on swimwear, beauty, and dieting also verged on being advertorial. The Waikato Times appeared to be considerably less clear than other papers in distinguishing between news and advertising.

Some overseas newspapers have also placed a greater emphasis on softer news to attract readers who are more interested in "private sphere" lifestyle and recreation stories than harder "public affairs" news (Beam, 2003, p. 373). Fairfax's chief executive also unashamedly believed that papers needed more soft news to attract readers and advertisers (Hilmer, 2007, p. 30). Although the prominence given to sports, entertainment and lifestyle stories in the media has been criticised, these stories play an important role in encouraging people to purchase newspapers and therefore pay even fleeting attention to wider events (Pankhurst, 2008, p. 40). 


\section{Focus on particular geographic areas}

Another way of examining the results is to consider the total amount of news about different places. Although the results treat sports and racing listings equally to front-page news stories, the data, which are available from the author, are nevertheless illuminating. The results confirm that news about events in its home city dominates each newspaper's New Zealand coverage. As expected from the Table 3 results, the Otago Daily Times printed the most news (over 30 pages) about its home city. The Christchurch Press was second on 23.1 pages, with many of its business and sports stories reporting events in Christchurch. The Waikato Times had 14.8 pages of news about Hamilton, while the Southland Times had 12.1 pages of news about Invercargill.

The Waikato Times printed 4.3 pages of news on the Waikato District, which is immediately north of Hamilton; 3.3 pages of news on the Waipa District, which is immediately south; and 2 pages on Matamata-Piako, which is a short distance east. The Waikato Times also printed 6.1 pages of news about the Waikato region in general, including sports and weather listings. Some stories on events in Hamilton, such as reports about Waikato sports teams, would also be of interest to people in other parts of the Waikato. Nevertheless, the Waikato Times had little specific news coverage of other districts in the Waikato.

The Christchurch Press printed even less news specifically about districts in its home region of Canterbury. However, the paper did print 1.3 pages of news about Timaru and 1.6 and 1.3 pages of news respectively about the neighbouring Nelson-Marlborough and West Coast regions. These results suggest the Press usually relies on other strengths, such as its strong national, business, and world news coverage, to attract readers outside Christchurch.

The Otago Daily Times printed 4.3 pages of news about the Waitaki District, where it was in competition with APN's five day a week Oamaru Mail. Although on most days in 2006 the Oamaru Mail was only 10 broadsheet pages, the Otago Daily Times had two journalists in Oamaru. During the week studied the Otago Daily Times also printed 1.9 pages of news about the Clutha District, four pages about Central Otago, and 4.8 pages about the Queenstown Lakes District.

In the latter two districts, it competes with the Southland Times' Queenstown and Central Otago edition, which contained 2.3 pages of news on Central Otago and 3.7 pages of news about Queenstown. The first five pages of 
the Southland Times' Queenstown and Central Otago edition differ from the Invercargill edition, and during the week studied there was always a Queenstown or Central Otago story above the front page fold. In December 2006 the Otago Daily Times employed a third Queenstown journalist, bringing them level with the Southland Times. Both papers also drew on stories from journalists in other Queenstown Lakes towns, and both had a photographer in Queenstown (Charteris \& Tulett, 2006; Morris, 2006, p. 11). In recent years the Southland Times and Otago Daily Times have each had readership rates of about $40 \%$ in the Queenstown area (Guthrie \& Julian, 2009, p. 2).

The Southland Times printed 3.8 pages of news specifically about the Southland District. Although the Otago Daily Times sells some copies in Southland, it has not been viable to offer home delivery in Invercargill, while the paper arrives too late in Te Anau to be widely read.

\section{Newspaper readership and quality in New Zealand}

A key measure of the success of a paper is its local readership rate (Meyer, 2009, pp. 16, 78-79, 125-126). The Waikato Times' local readership rate of 44 percent was the lowest of the papers studied, while the Otago Daily Times' 61 percent readership rate was the highest. The Southland Times had 57 percent local readership rate, while the Christchurch Press was second lowest on 50 percent. In Christchurch, Dunedin and Invercargill the home city newspaper is the only paper widely available and home delivered, although the papers compete outside these cities. In contrast, the

\section{Figure 1: Pages of news and local readership, 2006}

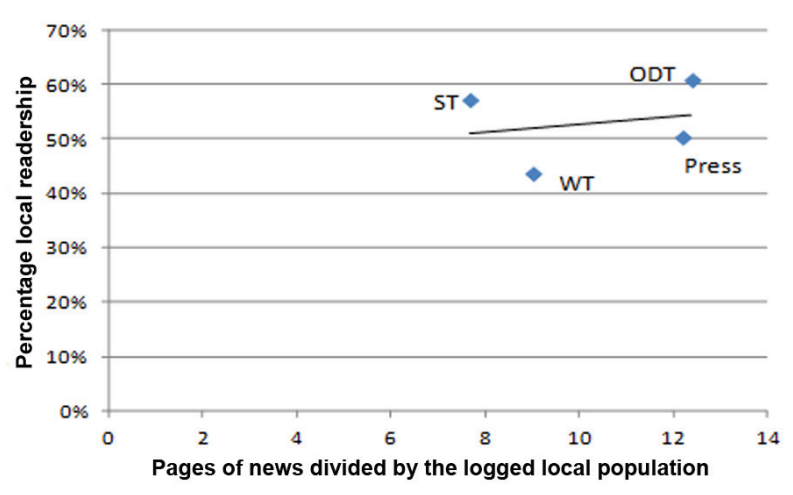


Waikato Times faces considerable competition in its home city. The New Zealand Herald, which is published 126 kilometres away in Auckland, is available from almost as many retailers in Hamilton as the Waikato Times, and is home delivered there. The Herald had a 13 percent readership rate in Hamilton in 2006.

Although there are a number of potentially confounding variables, and probably some simultaneous causality, researchers in other countries have found a statistical relationship between measures of newspaper quality and local readership (Chen et al., 2005, p. 527). Despite this study's small sample size, Figure 1 shows the relationship between pages of news, divided by logged local population, and local readership. Dividing pages of news by logged population controls for the tendency for a larger group of people to have more diverse and complex information needs, but for these needs to grow at a diminishing rate. A similar, but weaker, relationship was evident just using quantity of news as the independent variable.

The results show that the Otago Daily Times scored best on this quality measure and had the highest local readership, whereas the Waikato Times scored worst and had the lowest readership. The Christchurch Press was between these two newspapers. The Southland Times is an outlier because it had higher readership than predicted by the quantity of news it published. This suggests that other factors, such as its comparatively high number of local journalists and its low cover price, may be increasing its readership. Although the best-fit line suggests a relationship between pages of news and readership exits, the small sample size means that regression cannot show a statistical relationship. A much larger sample that tracked changes in the quality of newspapers over time would be necessary to reach strong conclusions about the relationship between newspaper quality and readership. However, because they are published in similar sized cities and have almost identical circulations, comparisons of the Otago Daily Times and the Waikato Times seem theoretically valid and informative. The results suggest that if the Waikato Times was a more substantial newspaper it would be better placed to compete with the New Zealand Herald for Waikato newspaper readers.

\section{Competition and investment strategies}

This article has found evidence that different New Zealand newspaper companies have different investment strategies, and that regional competition 
has been increasing newspaper quality in the South Island. However, despite APN's New Zealand Herald having a large readership in the Waikato Times' home city of Hamilton, in 2006 Fairfax's Waikato Times was a relatively weak paper. This suggests that the relationship between regional newspaper competition and quality is contingent on the management of newspapers deciding to compete. Although Waikato Times' readership had been consistently relatively low, INL appears to have accepted this situation. In contrast, after taking control Fairfax identified the Waikato Times as underperforming and made a number of changes in an effort to improve readership and advertising revenue.

The success of Fairfax's initial changes to the Waikato Times is difficult to evaluate. The readership of the Waikato Times has increased in some years and among some economic groups, but has decreased in other years. Although the Waikato Times' rate of circulation decline has been lower than for almost all newspapers in New Zealand, the Waikato region has experienced relatively rapid population growth.

Fairfax made a number of major changes to the Waikato Times during the second half of 2011, and in September 2011 switched the weekday paper to morning publication. Editorial improvements included a two page weekly farming section to cater for the Waikato's large farming sector, publishing additional letters once a week, adding a weekly regional history page, more coverage of world news, and increasing the Friday gardening section to two pages. The effects of this increase in hard and soft news are not yet evident.

The other papers included in this study have also made changes to their content and staffing. In particular, the Southland Times has increased its Queenstown and Central Otago staff and news coverage (Southland Times, 2011, p. E4). The Otago Daily Times launched a thrice weekly Queenstown Times supplement, then reduced the frequency of this supplement to once a week after acquiring the free Queenstown Mountain Scene newspaper in early 2013 (Otago Daily Times, 2013). Changes at the Press include a daily tabloid section, which usually includes entertainment, features, and lifestyles content previously published in the main body of the paper. Nevertheless, a comparison at the public library shows the similarities bet- ween the four papers surveyed in 2006 and more recent issues of the same papers are strong.

\section{Implications}

The competition between the Otago Daily Times and Southland Times over 
the Queenstown and Central Otago markets raises the question of why similar competition does not seem to be happening in some other parts of New Zealand. Perhaps one reason is that APN owns almost all the daily papers in the upper North Island (with the exception of Fairfax's Waikato Times). Fairfax owns almost all of the large daily papers south of Taupo, with the significant exception of the Otago Daily Times. There is little incentive for newspaper companies to allow their papers to compete with other papers owned by the company, because at best this would result in a transfer of readers and advertisers between newspapers owned by the company.

Admittedly APN's New Zealand Herald is widely available in Wellington (although less so than until 2012), but it focuses on national news. Fairfax's Dominion Post is now available north of Taupo in Bay of Plenty centres, such as Tauranga, Rotorua and Whakatane, where Fairfax publishes no newspapers. The Dominion Post is not widely available in Hamilton, however, where it would compete with the Waikato Times. Nor is the Dominion Post widely available in Auckland. This may reflect Fairfax's ownership of 12 free papers that cover most parts of Auckland. An Auckland edition of the Dominion Post could attract readers and advertisers away from these papers. In Queenstown, by contrast, Fairfax does not publish a free newspaper. There are therefore stronger incentives for Fairfax to pursue paid newspaper sales in Queenstown and in the Bay of Plenty than in Auckland. This suggests that less concentrated newspaper ownership in New Zealand could result in greater competition on cover, subscription and advertising prices (Molineaux, 1995, pp. 9-10), and an increase in the quality and readership of newspapers.

\section{Conclusion}

Content analysis results show that Allied Press' Otago Daily Times printed considerably more news and employed more journalists than New Zealand papers with similar circulations that were owned by the Australian company Fairfax. Indeed, the Otago Daily Times published almost as much news as the Christchurch Press, despite having less than half the circulation. The Otago Daily Times, which has the highest percentage of local readership of the papers in the sample, strongly focussed on local news, although its world and national news coverage was also substantial. The results support United States research that there are differences in investment strategies and attempts to attract readers between newspaper companies. Although the sample size is 
very small, the data also provided some support for the theory that producing a relatively high quality newspaper, defined in terms of the quantity of news published and the number of journalists employed, results in relatively high readership. High readership rates benefit publishers because they result in higher sales revenue and make a newspaper more attractive to advertisers.

The Otago Daily Times and Southland Times are currently vigorously competing for dominance of the fast-growing Queenstown market, with each paper employing journalists there and printing large quantities of Queenstown news to attract local readers. Apart from the lower half of the South Island, however, the high concentration of newspaper ownership has resulted in relatively little regional newspaper competition in New Zealand. Despite the passage of time, these results suggest that if there were more competing newspaper groups, competition between papers would be more vigorous and there would be less potential for newspapers to reduce staff numbers in search of short-term profits. As well as benefitting consumers, more dispersed ownership and greater competition would improve the democratic process by making it easier for people to be informed about political and economic events.

\section{Notes}

1. Robin Charteris, the outgoing editor of the Otago Daily Times, told Media Watch on 10 December 2007, that his paper had a regional reporting staff of eleven, while claiming the Press only had six for the whole South Island. He was presumably excluding staff in each paper's home city.

\section{References}

Beam, R. A. (2003). Content differences between daily newspapers with strong and weak market orientations. Journalism and Mass Communication Quarterly, 80(2), 368-390.

Beaudoin, C., \& Thorson, E. (2001). L.A. Times offered as model for foreign news coverage. Newspaper Research Journal, 22(1), 80-94.

Charteris, R., \& Tulett, F. (2006). Media Watch: Radio New Zealand.

Chen, R., Thorson, E., \& Lacy, S. (2005). The impact of newsroom investment on newspaper revenue and profits: Small and medium newspapers, 1998-2002. Journalism and Mass Communication Quarterly, 82(3), 516-532.

Cho, S., Thorson, E., \& Lacy, S. (2004). Increased circulation follows investments in newsroom. Newspaper Research Journal, 23(4), 26-39. 
Cohen, D. (26 November 2004). How to stop a newspaper from growing. National Business Review,

Ellis, G. (2010). Who owns the media? In R. Miller (Ed.), New Zealand government and politics. Auckland: Auckland University Press.

EPMU New Zealand Herald Journalists. (2009). EPMU Journalism Review: New Zealand Herald Journalists Branch Submission. Auckland.

Fairfax. (2004). Fairfax annual report 2004. Sydney.

Fan, Y. (2009). Market structure and product quality in the U.S. daily newspaper market. New Haven: Department of Economics, Yale.

Gentzkow, M., Shapiro, J. M., \& Sinkinson, M. (2011). The effect of newspaper entry and exit on electoral politics. American Economic Review, 101, 2980-3018.

Guthrie, J., \& Julian, L. (2009). Greater Queenstown/Arrowtown media survey 2009. Dunedin: University of Otago.

Hendery, S. (2009). Reading between the lines. AdMedia, 24(2).

Hilmer, F. a. B. D. (2007). The Fairfax experiment: What the management texts didn't teach me. Milton (Australia): John Wiley.

Hindman, D. B., \& Yamamoto, M. (2011). Social Capital in a Community Context: A Multilevel Analysis of Individual and Community-Level Predictors of Social Trust. Mass Communication and Society, 14(6), 838-856.

Kemp, G. (2010). Democracy, the public and the media. In R. Miller (Ed.), New Zealand government and politics (5th ed.). Auckland: Auckland University Press.

Lacy, S. (1988). The impact of intercity competition on daily newspaper content. Journalism Quarterly, 65(2), 399-406.

Lacy, S., \& Fico, F. (1990). Newspaper quality and ownership: Rating the groups. Newspaper Research Journal, 11(2), 42-56.

Lacy, S., \& Fico, F. (1991). The link between newspaper content quality and circulation. Newspaper Research Journal, 12(2), 46-57.

Max, L. (1986). Paper giant: Inside the Herald. Metro, 6(61), 34-57.

McGregor, J. (1996). Introduction. In J. McGregor (Ed.), Dangerous democracy: News media politics in New Zealand. Palmerston North: Dunlop Press.

Meyer, P. (2009). The vanishing newspaper: Saving journalism in the information age (2nd ed.). Columbia: University of Missouri Press.

Molineaux, J. (1995). Concentration of ownership in the New Zealand daily newspaper industry. New Zealand Journal of Media Studies, 2(2), 3-11.

Morris, C. (2006, 6 December). Morris returns to ODT. Otago Daily Times, p. 11,

Norris, P. (2000). A virtuous circle: Political communications in postindustrial democracies. Cambridge: Cambridge University Press.

Otago Daily Times. (2013, 5 April 2013). Queenstown Times changing. Otago Daily Times, from www.odt.co.nz/news/queenstown-lakes/251906/queenstown-timeschanging

Ovenden, K. (1987). How good are the provincial papers? North and South, 70-80.

Pankhurst, P. (2008). The power of print remains undiminished. Pacific Journalism Review, 14(1), 33-44. 
Riffe, D., Aust, C., \& Lacy, S. (1993). The effectiveness of random, consecutive day and constructed week sampling in newspaper content analysis. Journalism Quarterly, 70(1), 133-139.

Roger, W. (2002). Should that be the Post-Dominion? North and South(199), 95.

Rosenberg, B. (2007). The year of the accountant. Pacific Journalism Review, 14(1), 176-213.

Russell, M. (1991, December). Filling the void. Metro, 164.

Southland Times. (19 February 2011). Bureau Chief. Dominion Post, p. E4,

Statistics New Zealand. (2006). 2006 Census final counts. from www.stats.govt.nz/ Census/about-2006-census/final-counts-tables.aspx

Tansley, R. (2002). The prime of the Times. North and South(December).

Tryhorn, C. (1 March 2010). Regional papers run out of tricks to beat circulation slide. Guardian.

Warburton, E. (1954). A study of the press: Four New Zealand morning newspapers, Landfall, 8(3), 167-202.

Wilson, O. (3 December 2003). Fairfax man in his comfort zone. Independent, p. 26, from Newztext

Wood, G. A. (1975). The New Zealand news media: Political orientations and patterns of control. In S. Levine (Ed.), New Zealand politics: A reader (pp. 261-275). Melbourne: Cheshire.

Matthew Gibbons is an honorary research fellow, Politics Department, University of Waikato. He lives in Wellington and is a Dominion Post subscriber.

mgibbons@students.waikato.ac.nz 